\title{
Effect of seaweed-derived laminarin and fucoidan and zinc oxide on gut morphology, nutrient transporters, nutrient digestibility, growth performance and selected microbial populations in weaned pigs
}

\author{
G. Heim ${ }^{1}$, A. M. Walsh ${ }^{1}$, T. Sweeney ${ }^{2}$, D. N. Doyle ${ }^{1}$, C. J. O'Shea ${ }^{1}$, M. T. Ryan ${ }^{2}$ and J. V. O’Doherty ${ }^{1 *}$ \\ ${ }^{1}$ School of Agriculture and Food Science, University College Dublin, Belfield, Dublin 4, Republic of Ireland \\ ${ }^{2}$ School of Veterinary Medicine, University College Dublin, Belfield, Dublin 4, Republic of Ireland \\ (Submitted 9 July 2013 - Final revision received 15 November 2013 - Accepted 29 November 2013 - First published online 6 February 2014)
}

\section{Abstract}

In the present study, two experiments were conducted to (1) evaluate the effect of laminarin and/or fucoidan on ileal morphology, nutrient transporter gene expression and coefficient of total tract apparent digestibility (CTTAD) of nutrients and (2) determine whether laminarin inclusion could be used as an alternative to $\mathrm{ZnO}$ supplementation in weaned pig diets. Expt 1 was designed as a $2 \times 2$ factorial arrangement, comprising four dietary treatments ( $n 7$ replicates, weaning age $24 \mathrm{~d}$, live weight $6.9 \mathrm{~kg}$ ). The dietary treatments were as follows: (1) basal diet; (2) basal diet $+300 \mathrm{ppm}$ laminarin; (3) basal diet $+240 \mathrm{ppm}$ fucoidan; (4) basal diet $+300 \mathrm{ppm}$ laminarin and $240 \mathrm{ppm}$ fucoidan. There was an interaction between laminarin and fucoidan on the CTTAD of gross energy (GE) $(P<0.05)$ and the expression of sodium-glucose-linked transporter $1(S G L T 1 / S L C 5 A 1)$ and GLUT1/SLC2A1 and GLUT2/SLC2A2 $(P<0.05)$ in the ileum. The laminarin diet increased the CTTAD of GE and increased the expression of SGLT1, GLUT1 and GLUT2 compared with the basal diet. However, there was no effect of laminarin supplementation on these variables when combined with fucoidan. Expt 2 was designed as a complete randomised design $(n 8$ replicates/ treatment, weaning age $24 \mathrm{~d}$, live weight $7.0 \mathrm{~kg}$ ), and the treatments were (1) basal diet, (2) basal diet and laminarin (300 ppm), and (3) basal diet and $\mathrm{ZnO}(3100 \mathrm{ppm}, 0-14 \mathrm{~d}$, and $2600 \mathrm{ppm}, 15-32 \mathrm{~d}$ post-weaning). The laminarin diet increased average daily gain and gain: feed ratio compared with the basal diet during days $0-32$ post-weaning $(P<0 \cdot 01)$ and had an effect similar to the ZnO diet. These results demonstrate that laminarin provides a dietary means to improve gut health and growth performance post-weaning.

\section{Key words: Digestibility: Fucoidan: Laminarin: Nutrient transport: Pig performance: Zinc oxide}

The weaning of pigs in commercial production is quite abrupt and done at an early age $(14-28 \mathrm{~d} \text { after birth })^{(1,2)}$. It is characterised by changes in diet, separation from the sow, and environmental and social adaptations. These abrupt changes reduce the voluntary feed intake and disturb the health balance of the intestine ${ }^{(3)}$. The intestinal imbalance is associated with morphological and physiological changes that include intestinal inflammation, villous atrophy, crypt hyperplasia and reduced epithelial brush border activity ${ }^{(3,4)}$. Collectively, these factors favour diarrhoea, translocation of bacteria, and reduced digestive and absorptive capacity of small-intestinal enterocytes ${ }^{(4)}$, which result in a decrease in daily gain. In the past, the postweaning disorders were kept under control using antibiotic growth promoters in weaning pig diets ${ }^{(5)}$. High concentrations of dietary minerals, e.g. $\mathrm{Zn}$ in the form of $\mathrm{ZnO}$ at doses well above the requirements $(1000-3000 \mathrm{mg} / \mathrm{kg}$ feed), have been shown to decrease the incidence of post-weaning diarrhoea and gut disorders and to improve the growth performance of newly weaned pigs ${ }^{(6,7)}$. Current European legislation prohibits the incorporation of antibiotic growth promoters into animal diets (EC Regulation no. 1831/2003), and there are concerns within the European Union regarding the feeding of pharmacological doses of $\mathrm{ZnO}$ to pigs and the associated accumulation of $\mathrm{Zn}$ in the environment ${ }^{(8,9)}$.

Recently, studies have shown that dietary provision of a Laminaria spp.-derived seaweed extract containing laminarin and fucoidan promotes improved growth and feed efficiency in the absence of in-feed antibiotics ${ }^{(10,11)}$. It is known that seaweed extract supplementation modulates the gut environment, possesses potent antibacterial and immunomodulatory properties, and enhances growth performance partly through the improvement of the digestive and absorptive functions of the intestine ${ }^{(11-13)}$. It has been shown that laminarin and fucoidan supplementation after weaning improves

Abbreviations: ADFI, average daily feed intake; ADG, average daily gain; CD, crypt depth; CTTAD, coefficient of total tract apparent digestibility; G:F, gain:feed; GE, gross energy; SGLT, sodium-glucose-linked transporter; VFA, volatile fatty acids; VH, villus height. 
nutrient digestibility ${ }^{(14)}$. Nutrient digestibility can be improved by increasing villus height $(\mathrm{VH})$ in the small intestine and by increasing the numbers of nutrient transporters, e.g. mono saccharide transporters (sodium-glucose-linked transporters $(S G L T / S L C 5 A)$ and $G L U T / S L C 2 A)^{(15)}$, small-peptide (dipeptide and tripeptide) transporters $(P E P T / S L C 15 A)^{(16)}$ and unesterified long-chain fatty acid transporters (cluster of differentiation $36(C D 36 / F A T)$ and fatty acid-binding proteins $(F A B P / I-F A B P))^{(17,18)}$.

The hypothesis of the present study was that supplementation of the diet with laminarin and/or fucoidan after weaning would improve nutrient digestibility by improving gastrointestinal architecture in the small intestine as well as by increasing the numbers of nutrient transporters. A further objective was to determine whether laminarin inclusion could be considered as an alternative to $\mathrm{ZnO}$ supplementation.

\section{Materials and methods}

All experimental procedures were conducted under experimental licence from the Irish Department of Health in accordance with the Cruelty to Animals Act 1876 and the European Communities (Amendments of the Cruelty to Animals Act, 1876) Regulations (1994).

\section{Experimental design and animal management - Expt 1}

Expt 1 was designed as a $2 \times 2$ factorial arrangement, comprising four dietary treatments. The dietary treatments were as follows: (T1) basal diet (control); (T2) basal diet +300 parts per million (ppm) laminarin; (T3) basal diet $+240 \mathrm{ppm}$ fucoidan; (T4) basal diet $+300 \mathrm{ppm}$ laminarin and $240 \mathrm{ppm}$ fucoidan. Both laminarin and fucoidan were included in the diet during manufacture, and the concentrations of laminarin and fucoidan used were based on previous work carried out by Walsh et al. ${ }^{(14)}$. Laminarin $(990 \mathrm{~g}$ laminarin $/ \mathrm{kg})$ and fucoidan $(720 \mathrm{~g}$ fucoidan $/ \mathrm{kg}, 180 \mathrm{~g} / \mathrm{kg}$ crude protein and $100 \mathrm{~g} / \mathrm{kg}$ ash) were derived from Laminaria spp. and sourced from BioAtlantis Limited. The diets were provided ad libitum in a meal form after weaning for $9 \mathrm{~d}$, after which the pigs were humanely killed. The diets were formulated to have similar digestible energy $(14.5 \mathrm{MJ} / \mathrm{kg})$ and standardised ileal digestible lysine $(12.5 \mathrm{~g} / \mathrm{kg})$ contents. All amino acid requirements were met relative to lysine ${ }^{(19)}$. Ingredient composition and chemical analysis composition of the basal diet used in Expt 1 are given in Table 1.

For Expt 1, twenty-eight pigs (progeny of Large White $\times$ (Large White $\times$ Landrace sows)) were selected from a commercial pig unit at $24 \mathrm{~d}$ of age, with a weaning weight of $6.9 \mathrm{~kg}$ (SD $0.44 \mathrm{~kg}$ ). The pigs were blocked on the basis of litter of origin and body weight, and they were randomly assigned to one of the four dietary treatments ( $n 7$ replicates/treatment). The pigs were individually housed in a fully slatted pen $(1.68 \mathrm{~m} \times 1.22 \mathrm{~m})$. House temperature was thermostatically controlled at $30^{\circ} \mathrm{C}$ throughout the experiment. The pigs were fed ad libitum from a four-space feeder with trays placed underneath the feeder to avoid wastage of feed. Water was
Table 1. Ingredient composition and chemical analysis composition of the basal diet $(\mathrm{g} / \mathrm{kg}$, unless otherwise indicated) used in Expt 1 and 2

\begin{tabular}{|c|c|}
\hline & Basal diet \\
\hline \multicolumn{2}{|l|}{ Ingredient composition } \\
\hline Whey powder & $50 \cdot 0$ \\
\hline Wheat & $380 \cdot 0$ \\
\hline Soyabean meal & $170 \cdot 0$ \\
\hline Barley & 233.5 \\
\hline Full-fat soyabean & 120 \\
\hline Soya oil & $10 \cdot 0$ \\
\hline Vitamins and minerals* & 3.0 \\
\hline Salt & 3.0 \\
\hline Dicalcium phosphate & $12 \cdot 5$ \\
\hline Limestone & $11 \cdot 0$ \\
\hline Lys $\mathrm{HCl}$ & $4 \cdot 0$ \\
\hline DL-Met & 1.5 \\
\hline L-Thr & 1.5 \\
\hline \multicolumn{2}{|l|}{ Chemical analysis composition } \\
\hline DM & $866 \cdot 1$ \\
\hline Crude protein $(\mathrm{N} \times 6.25)$ & $210 \cdot 6$ \\
\hline Digestible energy $(\mathrm{MJ} / \mathrm{kg}) \dagger$ & 14.5 \\
\hline Ash & $48 \cdot 4$ \\
\hline Neutral-detergent fibre & $115 \cdot 1$ \\
\hline Lys† & 14.5 \\
\hline Met and Cys ${ }^{\star \star}$ & $8 \cdot 4$ \\
\hline Thrt & $9 \cdot 1$ \\
\hline Trp† & $2 \cdot 5$ \\
\hline Ca† & 9.5 \\
\hline $\mathrm{P}+$ & $6 \cdot 1$ \\
\hline \multicolumn{2}{|c|}{ 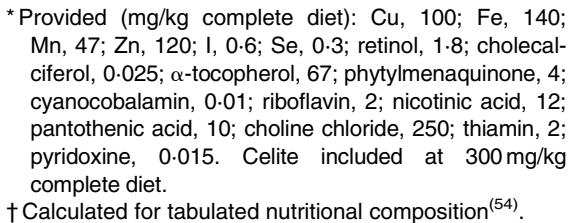 } \\
\hline
\end{tabular}

available from nipple drinkers at all time points. Food was available up to weighing of the pigs and then weighed back for the purpose of calculating feed intake. Representative feed samples of each dietary treatment were collected on day 0 . The pigs were weighed at the beginning of the experiment (day of weaning: day 0) and at the end of the experiment (day 9). Multiple fresh faecal samples were collected daily from all pens on days 6-9 for nutrient digestibility analyses using the acidinsoluble ash technique ${ }^{(20)}$.

On day 9, all pigs were weighted and humanely killed by lethal injection of Euthatal (Pentobarbitone sodium BP; Merial Animal Health Limited) to the cranial vena cava at a rate of $1 \mathrm{ml} / 1.4 \mathrm{~kg}$ body weight. On removal of the digestive tract, sections of the ileum ( $15 \mathrm{~cm}$ from caecum) were excised: one part was fixed in $10 \%$ phosphate-buffered formalin for morphological analysis and another part was opened along the mesentery, emptied and gently washed using sterile PBS (Oxoid) and stored in RNAlater solution (Applied Biosystems) overnight at $4^{\circ} \mathrm{C}$. RNAlater was then removed, and samples were stored at $-70^{\circ} \mathrm{C}$ until RNA extraction.

\section{Experimental design and animal management - Expt 2}

Expt 2 was designed as a complete randomised block design comprising three dietary treatments. The dietary treatments 
were as follows: (T1) basal diet (control); (T2) basal diet +300 ppm laminarin; (T3) basal diet $+3100 \mathrm{ppm} \mathrm{ZnO}$ from day 0 to day 14 and 2600 ppm ZnO from day 15 to day 32 . The concentrations of laminarin and $\mathrm{ZnO}$ used were based on previous work carried out by McDonnell et al. ${ }^{(11)}$ and O'Doherty et $a l .{ }^{(21)}$, respectively. Laminarin was derived from Laminaria spp. and sourced from BioAtlantis Limited, and $\mathrm{ZnO}$ was sourced from Provimi Limited. The diets were provided ad libitum in a meal form for $32 \mathrm{~d}$ after weaning. The diets were formulated to have similar digestible energy $(14.5 \mathrm{MJ} / \mathrm{kg})$ and standardised ileal digestible lysine $(12.5 \mathrm{~g} / \mathrm{kg})$ contents. All amino acid requirements were met relative to lysine ${ }^{(19)}$. Ingredient composition and chemical analysis composition of the basal diet used in Expt 2 are given in Table 1.

In Expt 2, forty-eight pigs (progeny of Large White $\times$ (Large White $\times$ Landrace sows)) weaned at $24 \mathrm{~d}$, with an initial weight of $7.0 \mathrm{~kg}$ (SD $0.67 \mathrm{~kg}$ ), were used. The pigs were blocked on the basis of live weight and litter of origin and were randomly assigned to one of the three treatments ( $n 8$ replicates/ treatment, $n 2$ pigs/replicate). The pigs were housed in pairs on a fully slatted pen $(1.68 \mathrm{~m} \times 1.22 \mathrm{~m})$. House temperature was thermostatically maintained at $30^{\circ} \mathrm{C}$ for the first $7 \mathrm{~d}$ and then reduced by $2^{\circ} \mathrm{C}$ per week. The pigs were weighed at the beginning of the experiment (day of weaning: day 0 ), day 7 , day 14, day 21 and day 32. The pigs were fed ad libitum from a four-space feeder with trays placed underneath the feeder to minimise wastage of feed. Water was available ad libitum from nipple drinkers. Food was available until the pigs were weighed and then weighed back for the purpose of calculating feed intake. Representative feed samples of each dietary treatment were collected at regular intervals throughout the experiment for chemical analysis. Multiple fresh faecal samples were collected daily from all pens on days $10-15$ for nutrient digestibility analyses using the acid-insoluble ash technique ${ }^{(20)}$ and volatile fatty acid (VFA) analyses. For VFA analyses, samples were mixed with sodium benzoate and phenylmethylsulphonyl fluoride to stop any bacterial activity and minimise the effects of post-thawing fermentation on resulting VFA. The samples were then stored at $-20^{\circ} \mathrm{C}$ for VFA analyses. Multiple fresh faecal samples were collected from all pens on day 10 and stored at $-20^{\circ} \mathrm{C}$ for microbial genomic DNA analysis.

\section{Laboratory analyses}

Ileum morphological analysis - Expt 1. Preserved ileal tissue samples were prepared using standard paraffin-embedding techniques. The samples were sectioned at a thickness of $5 \mu \mathrm{m}$ and stained with haemotoxylin and eosin ${ }^{(22)}$. VH and crypt depth (CD) were measured in the stained sections ( $4 \times$ objective) using a light microscope fitted with an image analyser (Image-Pro Plus; Media Cybernetics). Measurements of fifteen wellorientated and intact villi and crypts were taken for each segment. $\mathrm{VH}$ was measured from the crypt-villus junction to the tip of the villus, and CD was measured from the crypt-villus junction to the base. Results are expressed as mean VH or CD in $\mu \mathrm{m}$.

RNA extraction, complementary DNA synthesis and quantitative real-time $P C R$ - Expt 1. RNA was purified using the phenol-chloroform extraction method. Total RNA was extracted from approximately $50 \mathrm{mg}$ of tissue samples using the GenElute ${ }^{\mathrm{TM}}$ Mammalian Total RNA Miniprep Kit (Sigma-Aldrich) according to the manufacturer's instructions. Total RNA samples were treated with DNase I (Sigma-Aldrich). Total RNA was quantified using a NanoDrop-ND1000 spectrophotometer (Thermo Fisher Scientific, Inc.). RNA integrity was assessed on the Agilent 2100 Bioanalyzer, and all RNA integrity number values were $>8.9$ (Agilent Technology). Complementary DNA was synthesised from $1 \mu \mathrm{g}$ of total RNA using the Superscript ${ }^{\mathrm{TM}}$ III First-Strand Synthesis Kit (Invitrogen) and oligo(dt) primers following the manufacturer's instructions. The final reaction volume of $20 \mu \mathrm{l}$ was then adjusted to $120 \mu \mathrm{l}$ using nuclease-free water. The quantitative real-time PCR assay mixtures were prepared in a total volume of $20 \mu \mathrm{l}$, containing $10 \mu \mathrm{l}$ Fast SYBR PCR Master Mix (Applied Biosystems), 1.8 $\mu \mathrm{l}$ forward and reverse primer mix (300 nM), $5 \cdot 7 \mu$ l nuclease-free water and $2.5 \mu \mathrm{l}$ complementary DNA. Quantitative real-time PCR was carried out in duplicate on the 7500 ABI Prism Sequence Detection System (Applied Biosystems). Thermocycling conditions were as follows: $95^{\circ} \mathrm{C}$ for $10 \mathrm{~min}$ for one cycle, followed by $95^{\circ} \mathrm{C}$ for $15 \mathrm{~s}$ and $60^{\circ} \mathrm{C}$ for $1 \mathrm{~min}$ for forty cycles. Dissociation analyses of the PCR products confirmed the specificity of all targets. All primers for the selected nutrient transporters (PEPT1/SLC15A1, SGLT1/SLC5A1, GLUT1/SLC2A1, GLUT2/ SLC2A2, GLUT5/SLC2A5, GLUT7/SLC2A7, GLUT8/SLC2A8, $F A B P 2 / I-F A B P$ and $C D 36 / F A T$ ) are presented in Table 2. All primers were designed using the Primer Express ${ }^{\mathrm{TM}}$ Software (Applied Biosystems) and synthesised by MWG Biotech. Dissociation analyses of the PCR products were carried out to confirm the specificity of the resulting PCR products. All samples were prepared in duplicate. The mean cycle threshold values of duplicates of each sample were used for calculations. Normalised relative quantities were obtained using the qbase PLUS software (Biogazelle) from two stable housekeeping genes $(\beta-2-$ microglobulin (B2M) and peptidylprolyl isomerase A (PPIA)).

Extraction and quantification of microbial DNA from faecal samples - Expt 2. Microbial genomic DNA was extracted from faecal samples using the QIAamp DNA Stool Kit (Qiagen) in accordance with the manufacturer's instructions. The quantity and quality of DNA were assessed using a NanoDrop spectrophotometer (ND1000; Thermo Scientific). Standard curves were prepared as described by O'Shea et al. ${ }^{(23)}$. Briefly, genomic DNA from all faecal samples were pooled and amplified through routine PCR using Bifidobacterium, Lactobacillus spp. and Escherichia coli specific primers. For Bifidobacterium and Lactobacillus spp., the primer sequences were as follows: Bifidobacterium spp. - forward 5'-GCGTGCTTAACACATGCAAGTC- $3^{\prime}$ and reverse 5'-CACCCGTTTCCAGGAGCTATT- $3{ }^{\prime}, 59^{\circ} \mathrm{C}$, $125 \mathrm{bp}^{(25)}$; and Lactobacillus spp. forward $5^{\prime}$-AGCAGTAGGGAATCTTCCA- $3^{\prime}$ and reverse 5'-CACCGCTACACATGGAG- $3^{\prime}$, $55^{\circ} \mathrm{C}, 341 \mathrm{bp}^{(26)}$. Serial dilutions of these amplicons served to generate standard curves using quantitative real-time PCR (ABI 7500 Real-Time PCR System; Applied Biosystems Limited) permitting estimations of absolute quantification based on gene copy number ${ }^{(27)}$. Real-time PCR were carried out in a final reaction volume of $20 \mu \mathrm{l}$ containing $1 \mu \mathrm{l}$ template DNA, $1 \mu \mathrm{l}$ forward and reverse primers (100 pM), $10 \mu \mathrm{l}$ SYBR Green PCR Master Mix (Applied Biosystems) and $8 \mu$ l nuclease-free water. 
Table 2. Swine-specific primers used for real-time PCR in Expt 1

\begin{tabular}{|c|c|c|c|c|}
\hline Genes & Accession no. & Primer $\left(5^{\prime} \rightarrow 3^{\prime}\right)$ & Product length (bp) & $T_{\mathrm{m}}\left({ }^{\circ} \mathrm{C}\right)$ \\
\hline PEPT1 & NM_214347.1 & F: GGATAGCCTGTACCCCAAGCT & 73 & $61 \cdot 8$ \\
\hline SGLT1 & NM_001164021.1 & $\begin{array}{l}\text { R: CATCCTCCACGTGCTTCTTGA } \\
\text { F: GGCTGGACGAAGTATGGTGT } \\
\text { R: ACAACCACCCAAATCAGAGC }\end{array}$ & 153 & $\begin{array}{l}59 \cdot 8 \\
59 \cdot 4 \\
57 \cdot 3\end{array}$ \\
\hline GLUT1 & XM_003482115.1 & $\begin{array}{l}\text { F: TGCTCATCAACCGCAATGA } \\
\text { R: GTTCCGCGCAGCTTCTTC }\end{array}$ & 61 & $\begin{array}{l}54.5 \\
58 \cdot 2\end{array}$ \\
\hline GLUT2 & AF054835.1 & $\begin{array}{l}\text { F: CCAGGCCCCATCCCCTGGTT } \\
\text { R: GCGGGTCCAGTTGCTGAATGC }\end{array}$ & 96 & $\begin{array}{l}65 \cdot 5 \\
63 \cdot 7\end{array}$ \\
\hline GLUT5 & EU012359.2 & $\begin{array}{l}\text { F: CCCAGGAGCCGGTCAAG } \\
\text { R: TCAGCGTCGCCAAAGCA }\end{array}$ & 60 & $\begin{array}{l}60 \cdot 0 \\
55 \cdot 2\end{array}$ \\
\hline GLUT7 & XM_003127552.3 & $\begin{array}{l}\text { F: ACATCGCCGGACATTCCATA } \\
\text { R: GCGAGGACTGCAGGAAGATC }\end{array}$ & 75 & $\begin{array}{l}57 \cdot 3 \\
61 \cdot 4\end{array}$ \\
\hline GLUT8 & XM_003480608.1 & $\begin{array}{l}\text { F: AGCGCCTTTGGCACCTACTT } \\
\text { R: TGCACGTGCGAGGAGTTG }\end{array}$ & 62 & $\begin{array}{l}59 \cdot 4 \\
58 \cdot 2\end{array}$ \\
\hline FABP2 & NM_001031780.1 & $\begin{array}{l}\text { F: TCGGGATGAAATGGTCCAGACT } \\
\text { R: TGTGTTCTGGGCTGTGCTCCA }\end{array}$ & 102 & $\begin{array}{l}62.4 \\
61.8\end{array}$ \\
\hline$C D 36$ & NM_001044622.1 & $\begin{array}{l}\text { R: GGAGAAAAGATCACTACCATCATGAG } \\
\text { F: CTCCTGAAGTGCAATGTACTGACA }\end{array}$ & 78 & $\begin{array}{l}61 \cdot 6 \\
61 \cdot 0\end{array}$ \\
\hline PPIA & NM_214353.1 & $\begin{array}{l}\text { F: CGGGTCCTGGCATCTTGT } \\
\text { R: TGGCAGTGCAAATGAAAAACTG }\end{array}$ & 75 & $\begin{array}{l}58 \cdot 0 \\
56 \cdot 5\end{array}$ \\
\hline$B 2 M$ & NM_213978.1 & $\begin{array}{l}\text { F: CGGAAAGCCAAATTACCTGAAC } \\
\text { R: TCTCCCCGTTTTTCAGCAAAT }\end{array}$ & 83 & $\begin{array}{l}59 \cdot 0 \\
60 \cdot 0\end{array}$ \\
\hline
\end{tabular}

PEPT, peptide transporter; $\mathrm{F}$, forward; R, reverse; $S G L T$, sodium-glucose-linked transporter; $F A B P$, fatty acid-binding protein; $C D 36$, cluster of differentiation 36; PPIA, peptidylprolyl isomerase $A ; B 2 M, \beta-2$-microglobulin.

The thermal cycling conditions involved an initial denaturation step at $95^{\circ} \mathrm{C}$ for $10 \mathrm{~min}$ followed by forty cycles of $95^{\circ} \mathrm{C}$ for $15 \mathrm{~s}$ and $65^{\circ} \mathrm{C}$ for $1 \mathrm{~min}$. Dissociation analyses of the PCR products were carried out to confirm the specificity of the resulting PCR products.

To enhance the specificity of $E$. coli detection, a dual-labelled probe containing 6-carboxyfluorescein as the reporter dye and 6-carboxytetramethylrhodamine as the $3^{\prime}$ quencher dye was used (MWG Operon). The primer and probe sequence set for $E$. coli were as follows: forward 5'-CATGCCGCGTGTATGAAGAA- $3^{\prime}, \quad 5^{\prime}$-CGGGTAACGTCAATGAGCAAA- $3^{\prime}$ (probe), $59^{\circ} \mathrm{C}$, reverse $5^{\prime}$-TATTAACTTTACTCCCTTCCTCCCCGCTGAA- $3^{\prime}, 68^{\circ} \mathrm{C}$, $96 \mathrm{bp}^{(24)}$. The real-time PCR was carried out in a final reaction volume of $20 \mu \mathrm{l}$, containing $1 \mu \mathrm{l}$ template DNA, $1 \mu \mathrm{l}$ forward and reverse primers (100 pm), $1 \mu$ l probe (250 nm), $8 \mu$ l Mastermix 16S Basic, $0.64 \mu \mathrm{l} \mathrm{Taq}$ polymerase (Molzym) and $8.36 \mu$ l nucleasefree water. Thermocycling conditions during PCR were as those described above, apart from the absence of an initial denaturation step. Thus, reagents were prepared on ice. The mean threshold cycle values from the triplicate of each sample were used for calculations. Estimates of gene copy numbers for selected bacteria were log-transformed, and they are presented as gene copy numbers/g fresh faeces.

Coefficient of total tract apparent digestibility - Expt 1 and 2. Feed and faecal samples were analysed for N, DM, organic matter, ash, gross energy (GE) and neutral-detergent fibre (NDF). Following collection, faecal samples were dried at $100^{\circ} \mathrm{C}$ for $48 \mathrm{~h}$. The feed samples and dried faecal samples were milled through a $1 \mathrm{~mm}$ screen (Christy and Norris Hammer Mill). DM content was determined after drying overnight at $103^{\circ} \mathrm{C}$. Ash content was determined after ignition of a known weight of concentrates in a muffle furnace
(Nabertherm) at $500^{\circ} \mathrm{C}$ for $4 \mathrm{~h}$. $\mathrm{N}$ content was determined using the LECO FP 528 instrument (Leco Instruments). Neutraldetergent fibre content was determined according to the method of Van Soest et al. ${ }^{(28)}$ using the Ankom 220 Fibre Analyser (Ankom ${ }^{\mathrm{TM}}$ Technology). GE content was determined using a Parr 1201 oxygen bomb calorimeter (Parr). Total laminarin content in the diets was determined using a commercial assay kit (K-YBGL; Megazyme International Ireland Limited). Fucoidan content in the diets was determined according to the method described by Usov et al. ${ }^{(29)}$. Thawed faecal samples were analysed for VFA concentration and profile using the method of O'Connell et al. ${ }^{(30)}$.

\section{Statistical analysis}

The experimental data were analysed as a $2 \times 2$ factorial, randomised complete block design using the general linear model procedure of SAS (version 6.12; SAS Institute, Inc.). The statistical model used included the main effects of laminarin, fucoidan and block and the associated interaction between laminarin and fucoidan. In Expt 2, data were analysed as a complete randomised block design. The model included block and treatment and their associated interaction. The pig was the experimental unit in Expt 1, while pen was the experimental unit in Expt 2. All the data were initially checked for normality using the PROC univariate procedure in SAS (version 6.12; SAS Institute, Inc.). Gene copy estimates of selected bacteria and nutrient transporters were log-transformed before statistical analysis. The probability level that denotes significance is $P<0.05$, while $P$ values between 0.05 and $0 \cdot 1$ are considered numerical tendencies. Data are presented as least-square means with their standard errors. 
Table 3. Effects of dietary laminarin and fucoidan on pig growth performance (0-9d) and nutrient digestibility coefficient in Expt 1 (Least-square mean values with their standard errors)

\begin{tabular}{|c|c|c|c|c|c|c|c|c|}
\hline \multirow[b]{2}{*}{ Treatment... } & \multirow[b]{2}{*}{ Control } & \multirow[b]{2}{*}{ LAM } & \multirow[b]{2}{*}{ FUC } & \multirow[b]{2}{*}{$\mathrm{LAM}+\mathrm{FUC}$} & \multirow[b]{2}{*}{ SEM } & \multicolumn{3}{|c|}{$P$} \\
\hline & & & & & & LAM & FUC & LAM $\times$ FUC \\
\hline Laminarin & No & Yes & No & Yes & & & & \\
\hline Fucoidan & No & No & Yes & Yes & & & & \\
\hline \multicolumn{9}{|c|}{ Growth performance } \\
\hline$A D G(g / d)$ & 63 & 65 & 44 & 59 & 12 & NS & NS & NS \\
\hline $\operatorname{ADFI}(\mathrm{g} / \mathrm{d})$ & 181 & 182 & 172 & 197 & 13 & NS & NS & NS \\
\hline G:F ratio (g/kg) & 331 & 322 & 229 & 335 & 59 & NS & NS & NS \\
\hline \multicolumn{9}{|l|}{ CTTAD $(\mathrm{g} / \mathrm{kg})$} \\
\hline DM & 784 & 846 & 809 & 819 & 8.0 & * & NS & * \\
\hline $\mathrm{N}$ & 770 & 821 & 782 & 791 & $13 \cdot 0$ & * & NS & NS \\
\hline Ash & 357 & 564 & 471 & 509 & $28 \cdot 0$ & * & NS & * \\
\hline Gross energy & 768 & 833 & 790 & 801 & $9 \cdot 0$ & * & NS & * \\
\hline
\end{tabular}

Results

\section{Expt 1}

Performance - 0 to $9 d$. No difference was recorded in average daily gain (ADG), average daily feed intake (ADFI) and gain:feed (G:F) ratio among the treatment groups $(P>0.05$; Table 3$)$.

Coefficient of total tract apparent digestibility. The effects of laminarin and fucoidan supplementation on the coefficient of total tract apparent digestibility (CTTAD) of nutrients are presented in Table 3. There was an interaction between laminarin and fucoidan on the CTTAD of DM, ash and GE $(P<0.05)$. Pigs fed the laminarin diet alone had increased CTTAD of DM, ash and GE compared with those fed the basal diet. However, there was no effect of laminarin supplementation on the CTTAD of DM, ash and GE when combined with fucoidan. Laminarin supplementation increased the CTTAD of $\mathrm{N}$ compared with the non-laminarin treatments $(P<0.05)$. lleal morphology. There was no effect of laminarin or fucoidan supplementation on $\mathrm{VH}, \mathrm{CD}$ or $\mathrm{VH}: \mathrm{CD}$ (VH:CD) ratio in the ileum $(P>0.05)$. The overall mean for $\mathrm{VH}, \mathrm{CD}$ and $\mathrm{VH}: \mathrm{CD}$ ratio was $265 \cdot 8 \mu \mathrm{m}, 267 \cdot 3 \mu \mathrm{m}$ and $1 \cdot 0$, respectively.

Gene expression of nutrient transporters in the ileum on day 9. There was an interaction between laminarin and fucoidan on GLUT1, GLUT2 and SGLT1 expression $(P<0.05)$ in the ileum. Pigs fed the laminarin diet alone had increased GLUT1, GLUT2 and SGLT1 expression compared with those fed the basal diet. However, there was no effect of laminarin supplementation on GLUT1, GLUT2 and SGLT1 expression when combined with fucoidan. There were no effects of dietary treatments on PEPT1, GLUT5, GLUT7, GLUT8, CD36 and FABP2 $(P>0.05)$ expression (Table 4$)$.

\section{Expt 2}

Performance. The effects of laminarin and $\mathrm{ZnO}$ supplementation on ADG, ADFI and G:F ratio are presented in Table 5.

Table 4. Effects of fucoidan and laminarin supplementation on the normalised relative abundance of nutrient transporter mRNA in the ileal tissue of weaned pigs

(Least-square mean values with their standard errors)

\begin{tabular}{|c|c|c|c|c|c|c|c|c|}
\hline \multirow[b]{2}{*}{ Treatment... } & \multirow[b]{2}{*}{ Control } & \multirow[b]{2}{*}{ LAM } & \multirow[b]{2}{*}{ FUC } & \multirow[b]{2}{*}{ LAM+FUC } & \multirow[b]{2}{*}{ SEM } & \multicolumn{3}{|c|}{$P$} \\
\hline & & & & & & LAM & FUC & $\mathrm{LAM} \times \mathrm{FUC}$ \\
\hline Laminarin & No & Yes & No & Yes & & & & \\
\hline Fucoidan & No & No & Yes & Yes & & & & \\
\hline PEPT1 & 0.932 & 1.530 & 1.088 & $1 \cdot 164$ & 0.204 & NS & NS & NS \\
\hline SGLT1 & $0.896^{a}$ & $1 \cdot 687^{b}$ & $1 \cdot 153^{a, b}$ & $1 \cdot 000^{a, b}$ & 0.186 & * & NS & $\star$ \\
\hline GLUT1 & $1 \cdot 017^{a}$ & $1.472^{\mathrm{b}}$ & $1 \cdot 153^{a, b}$ & $0.887^{a}$ & 0.101 & * & NS & * \\
\hline GLUT2 & $1.034^{a}$ & $2 \cdot 174^{\mathrm{b}}$ & $1 \cdot 283^{a}$ & $1 \cdot 043^{a}$ & 0.208 & * & NS & * \\
\hline GLUT5 & 0.843 & $1 \cdot 254$ & $1 \cdot 328$ & $1 \cdot 208$ & 0.170 & NS & NS & NS \\
\hline GLUT7 & 0.983 & 1.788 & 1.380 & 1.930 & 0.350 & NS & NS & NS \\
\hline GLUT8 & 1.057 & 0.980 & 0.948 & 0.997 & 0.053 & NS & NS & NS \\
\hline FABP2 & $1 \cdot 207$ & 1.518 & 0.784 & 0.758 & $0 \cdot 201$ & NS & NS & NS \\
\hline$C D 36$ & 0.821 & $1 \cdot 230$ & 1.115 & 1.254 & 0.160 & NS & NS & NS \\
\hline
\end{tabular}

Control, basal diet; LAM, basal diet + 300 parts per million (ppm) laminarin; FUC, basal diet + 240 ppm fucoidan; LAM + FUC basal diet $+300 \mathrm{ppm}$ laminarin and $240 \mathrm{ppm}$ fucoidan; $P E P T$, peptide transporter; $S G L T$, sodium-glucose-linked transporter; $F A B P$, fatty acid-binding protein; $C D 36$, cluster of differentiation 36 .

${ }^{a, b}$ Mean values within a row with unlike superscript letters were significantly different $(P<0.05)$.

${ }^{*} P<0.05$. 
Table 5. Effects of laminarin and zinc oxide supplementation on pig performance in Expt 2

(Least-square mean values with their standard errors)

\begin{tabular}{lllll}
\hline Treatment... & Control & LAM & ZnO & SEM \\
\hline ADG (g/d) & & & & \\
$0-7 \mathrm{~d}$ & 26 & 35 & 58 & 20 \\
$7-14 \mathrm{~d}$ & $204^{\mathrm{a}, \mathrm{b}}$ & $195^{\mathrm{a}}$ & $255^{\mathrm{b}}$ & 20 \\
$14-21 \mathrm{~d}$ & $289^{\mathrm{a}}$ & $420^{\mathrm{b}}$ & $331^{\mathrm{a}}$ & 27 \\
$21-32 \mathrm{~d}$ & $483^{\mathrm{a}}$ & $576^{\mathrm{b}}$ & $484^{\mathrm{a}}$ & 24 \\
$0-32 \mathrm{~d}$ & $280^{\mathrm{a}}$ & $353^{\mathrm{b}}$ & $308^{\mathrm{a}, \mathrm{b}}$ & 16 \\
ADFI (g/d) & & & & \\
$0-7 \mathrm{~d}$ & 139 & 142 & 135 & 14 \\
$7-14 \mathrm{~d}$ & 364 & 366 & 399 & 30 \\
$14-21 \mathrm{~d}$ & 521 & 603 & 571 & 35 \\
$21-32 \mathrm{~d}$ & 853 & 908 & 843 & 52 \\
$0-32 \mathrm{~d}$ & 513 & 556 & 532 & 28 \\
G:F ratio (g/kg) & & & & \\
$0-7 \mathrm{~d}$ & 149 & 199 & 271 & 13 \\
$7-14 \mathrm{~d}$ & $568^{\mathrm{a}, \mathrm{b}}$ & $534^{\mathrm{a}}$ & $638^{\mathrm{b}}$ & 3 \\
$14-21 \mathrm{~d}$ & 552 & 634 & 584 & 3 \\
$21-32 \mathrm{~d}$ & 568 & 661 & 581 & 4 \\
$0-32 \mathrm{~d}$ & $514^{\mathrm{a}}$ & $608^{\mathrm{b}}$ & $580^{\mathrm{a}, \mathrm{b}}$ & 2 \\
\hline
\end{tabular}

Control, basal diet; LAM, basal diet +300 parts per million (ppm) laminarin; $\mathrm{ZnO}$, basal diet $+3100 \mathrm{ppm} \mathrm{ZnO}$ from day 0 to day 14 and $2600 \mathrm{ppm}$ of $\mathrm{ZnO}$ from day 15 to day 32; ADG, average daily gain; ADFI, average daily feed intake; G:F, gain:feed.

${ }^{a, b}$ Mean values within a row with unlike superscript letters were significantly different $(P<0.05)$.

Neither laminarin nor $\mathrm{ZnO}$ supplementation affected ADG, ADFI and G:F ratio during the first $7 \mathrm{~d}$ post-weaning $(P>0 \cdot 1)$. Pigs fed the $\mathrm{ZnO}$ diet had increased ADG and G:F ratio compared with those fed the laminarin diet $(P<0.05)$ during days 7-14. Pigs fed the laminarin diet had higher ADG $(P<0.05)$ compared with those fed the basal and $\mathrm{ZnO}$ diets during days 14-21 and 21-32. Pigs fed the laminarin diet had higher $(P<0.05)$ ADG and G:F ratio compared with those fed the basal diet during the whole study period (days $0-32$ ). There was no difference in the effects of the laminarin and $\mathrm{ZnO}$ diets on $\mathrm{ADG}$ and $\mathrm{G}: \mathrm{F}$ ratio during the whole study period $(P>0.05)$.

Coefficient of total tract apparent digestibility. The effects of laminarin and $\mathrm{ZnO}$ supplementation on the CTTAD of nutrients are presented in Table 6. The laminarin diet increased the CTTAD of DM, organic matter, ash, neutraldetergent fibre and GE compared with the basal and $\mathrm{ZnO}$ diets $(P<0.05)$. There was a decrease in the CTTAD of DM, organic matter, ash, GE and $\mathrm{N}$ in pigs fed the $\mathrm{ZnO}$ diet compared with that in pigs fed the basal and laminarin diets $(P<0 \cdot 05)$. Pigs fed the ZnO diet had lower CTTAD of neutraldetergent fibre compared with those fed the laminarin diet.

Faecal microbiology and volatile fatty acids. The effects of laminarin and $\mathrm{ZnO}$ supplementation on selected faecal microbial populations and faecal VFA are presented in Table 7 . Pigs fed the ZnO diet had decreased populations of $E$. coli and Bifidobacterium compared with those fed the basal and laminarin diets. Pigs fed the laminarin diet had increased numbers of Lactobacillus spp. compared with those fed the basal and $\mathrm{ZnO}$ diets

Pigs fed the ZnO diet had a decreased total faecal VFA concentration compared with those fed the basal diet $(P<0 \cdot 01)$. There was no effect of laminarin supplementation on total VFA concentration $(P>0 \cdot 05)$. Pigs fed the $\mathrm{ZnO}$ diet had a decreased proportion of acetic acid, isobutyric acid, butyric acid, isovaleric acid and valeric acid compared with those fed the basal diet $(P<0 \cdot 05)$. Pigs fed the laminarin diet had a lower proportion of propionic acid compared with those fed the basal diet $(P<0.05)$

\section{Discussion}

The hypothesis of Expt 1 was that supplementation with laminarin and fucoidan, independently or in combination, increases nutrient digestibility in weaned pigs through an improved gastrointestinal architecture in the small intestine and an increased number of nutrient transporters. A further objective was to determine whether laminarin inclusion could be considered as an alternative to $\mathrm{ZnO}$ supplementation in weaned pig diets. The results of the present study demonstrate that laminarin supplementation increases the expression of GLUT in the ileum (SGLT1, GLUT1 and GLUT2). This improvement might be related to the improvement in nutrient digestibility of the diet. Furthermore, in Expt 2, laminarin supplementation improved growth performance after 2 weeks post-weaning. This was probably through improved nutrient digestibility and increased number of Lactobacillus spp.

In Expt 1, the performance levels were similar between the treatment groups. The lack of response in growth performance was probably due to the duration of the experiment (9d). However, longer duration studies (e.g. 21d) have shown positive effects of laminarin and fucoidan on ADG and $G: F$ ratio ${ }^{(11,31)}$. Pigs fed the laminarin diet alone had increased CTTAD of DM, ash, N and GE. Nutrient digestibility can be increased by improving $\mathrm{VH}$ in the small-intestinal epithelium and by increasing the numbers of nutrient transporters during the weaning period. Changes in the diet and reduction in voluntary feed intake during the weaning period result in intestinal villous atrophy and crypt hyperplasia $^{(3,4)}$, and as a consequence, the expression of nutrient transporters is down-regulated ${ }^{(32,33)}$. In Expt 1, there was no difference in $\mathrm{VH}, \mathrm{CD}$ and $\mathrm{VH}: \mathrm{CD}$ ratio in the ileum between the treatment groups, resulting in similar absorptive area between the treatment groups. In an identical experiment,

Table 6. Effects of dietary treatment on the coefficient of total tract apparent digestibility (CTTAD, g/kg) in Expt 2 (Least-square mean values with their standard errors)

\begin{tabular}{lcrrr}
\hline Treatment... & Control & LAM & ZnO & SEM \\
\hline DM & $715^{\mathrm{b}}$ & $761^{\mathrm{c}}$ & $639^{\mathrm{a}}$ & 13 \\
OM & $743^{\mathrm{b}}$ & $783^{\mathrm{c}}$ & $677^{\mathrm{a}}$ & 12 \\
N & $723^{\mathrm{b}}$ & $711^{\mathrm{b}}$ & $621^{\mathrm{a}}$ & 18 \\
Ash & $19^{\mathrm{b}}$ & $34^{\mathrm{c}}$ & $-1^{\mathrm{a}}$ & 4 \\
NDF & $129^{\mathrm{a}}$ & $260^{\mathrm{b}}$ & $60^{\mathrm{a}}$ & 30 \\
GE & $677^{\mathrm{b}}$ & $725^{\mathrm{c}}$ & $608^{\mathrm{a}}$ & 16 \\
\hline
\end{tabular}

Control, basal diet; LAM, basal diet +300 parts per million (ppm) laminarin; $\mathrm{ZnO}$, basal diet $+3100 \mathrm{ppm} \mathrm{ZnO}$ from day 0 to day 14 and $2600 \mathrm{ppm}$ of $\mathrm{ZnO}$ from day 15 to day 32; OM, organic matter; NDF, neutral-detergent fibre; GE, gross energy.

${ }^{a, b, c}$ Mean values within a row with unlike superscript letters were significantly different $(P<0.05)$. 
Table 7. Effects of laminarin and $\mathrm{ZnO}$ supplementation on faecal populations of Escherichia coli, Bifidobacterium and Lactobacillus spp. and concentrations of faecal volatile fatty acids (VFA) in Expt 2

(Least-square mean values with their standard errors)

\begin{tabular}{|c|c|c|c|c|}
\hline Treatment... & Control & LAM & $\mathrm{ZnO}$ & SEM \\
\hline E. coli ${ }^{*}$ & $9 \cdot 4^{\mathrm{b}}$ & $9 \cdot 3^{\mathrm{b}}$ & $8 \cdot 4^{\mathrm{a}}$ & 0.3 \\
\hline Lactobacillus spp.* & $10 \cdot 9^{a, b}$ & $11 \cdot 1^{\mathrm{b}}$ & $10 \cdot 8^{a}$ & 0.1 \\
\hline Bifidobacterium $^{\star}$ & $8 \cdot 7^{\mathrm{b}}$ & $8.9^{b}$ & $7 \cdot 4^{\mathrm{a}}$ & 0.3 \\
\hline Total VFA (mmol/g digesta) & $98 \cdot 1^{\mathrm{b}}$ & $83 \cdot 2^{\mathrm{a}, \mathrm{b}}$ & $75 \cdot 2^{a}$ & $5 \cdot 8$ \\
\hline Acetic acid & $59 \cdot 6^{\mathrm{b}}$ & $52 \cdot 8^{a, b}$ & $46 \cdot 5^{\mathrm{a}}$ & 4.0 \\
\hline Propionic acid & $18 \cdot 5^{\mathrm{b}}$ & $14 \cdot 5^{\mathrm{a}}$ & $16 \cdot 2^{\mathrm{a}, \mathrm{b}}$ & 1.3 \\
\hline Isobutyric acid & $2 \cdot 8^{\mathrm{b}}$ & $2 \cdot 8^{\mathrm{a}, \mathrm{b}}$ & $2 \cdot 2^{\mathrm{a}}$ & 0.2 \\
\hline Butyric acid & $9 \cdot 4^{\mathrm{b}}$ & $7 \cdot 1^{a, b}$ & $5 \cdot 9^{a}$ & 1.0 \\
\hline Isovaleric acid & $4 \cdot 6^{\mathrm{b}}$ & $3 \cdot 8^{\mathrm{a}, \mathrm{b}}$ & $3 \cdot 1^{\mathrm{a}}$ & 0.3 \\
\hline Valeric acid & $3.1^{\mathrm{b}}$ & $2 \cdot 6^{\mathrm{b}}$ & $1 \cdot 3^{\mathrm{a}}$ & 0.3 \\
\hline
\end{tabular}

Control, basal diet; LAM, basal diet +300 parts per million $(\mathrm{ppm})$ laminarin; $\mathrm{ZnO}$ basal diet $+3100 \mathrm{ppm} \mathrm{ZnO}$ from day 0 to day 14 and $2600 \mathrm{ppm} \mathrm{ZnO}$ from day 15 to day 32.

${ }^{\mathrm{a}, \mathrm{b}}$ Mean values within a row with unlike superscript letters were significantly different $(P<0.05)$

${ }^{*} \log _{10}$ colony-forming units/g digesta.

Walsh et $a l^{(14)}$ found no significant effect of laminarin or fucoidan on $\mathrm{VH}$ in either the ileum or the jejunum. However, supplementation with both laminarin and fucoidan significantly increased $\mathrm{VH}$ and $\mathrm{VH}: \mathrm{CD}$ ratio in the duodenum.

Pigs fed the laminarin diet had higher SGLT1, GLUT1 and GLUT2 expression in the ileum, which may partially explain the increase in nutrient digestibility in this group of pigs, as these nutrient transporters are responsible for transporting glucose from the intestinal lumen to the enterocyte and then to the blood stream. The protein levels of SGLT1 and GLUT2 are crucial to the absorption and uptake of glucose in the small intestine ${ }^{(34,35)}$. A wide range of monosaccharides are effective in enhancing the expression of GLUT ${ }^{(36,37)}$. The up-regulation of GLUT (SGLT1, GLUT1 and GLUT2) expression with laminarin supplementation in the present study may be due to the chemical structure $(\beta-(1 \rightarrow 3)$-linked glucans with $\beta$-(1 $\rightarrow 6)$-linked side chains $)^{(38,39)}$ and/or molecular weight (approximately $5 \mathrm{kDa})^{(40)}$ of laminarin. Fucoidan has a higher molecular weight $(43-1600 \mathrm{kDa})^{(40)}$ and a different structure (fucose-linked in $\alpha-(1 \rightarrow 3)$ containing sulphated polysaccharides $)^{(41)}$. This may explain the absence of an effect of fucoidan on the up-regulation of nutrient transporter expression

In Expt 2, dietary treatments did not affect pig performance during the first week post-weaning. During the second week, pigs fed the $\mathrm{ZnO}$ diet had higher ADG and G:F ratio compared with those fed the laminarin diet. However, during the third and fourth weeks, pigs fed the laminarin diet had higher ADG and G:F ratio compared with those fed the basal and $\mathrm{ZnO}$ diets. There was no effect of laminarin or $\mathrm{ZnO}$ supplementation on ADFI. Carlson et al. ${ }^{(42)}$ suggested that nursery pigs need to be fed ZnO-supplemented diets for at least 2 weeks after weaning for any growth-promoting effects to become apparent, implying that at least 1 week pre-test (or preloading) period may be required for clear $\mathrm{ZnO}$ responses in growth rate. Increased growth without an associated increase in feed intake indicates that the effects of laminarin and $\mathrm{ZnO}$ on growth performance involve a more complex mechanism than simply enhancing feed intake.

The mode of action of $\mathrm{ZnO}$ and its associated growthpromoting effects in the young pig remains unclear. The improvement in growth in Expt 2 could be due to a number of reasons. First, the higher growth rate of pigs fed the $\mathrm{ZnO}$ diet observed in the second week of Expt 2 may be attributable to the reduction in $E$. coli population. In studies carried out by different authors ${ }^{(6,7,43-45)}$, dietary $\mathrm{ZnO}$ has been shown to reduce the incidence of diarrhoea in weaned pigs, by reducing $E$. coli colonisation. Second, the decrease in $E$. coli population in pigs fed the $\mathrm{ZnO}$ diet was also associated with a reduction in protein fermentation in the colon. The reduction in the concentrations of isobutyric acid, isovaleric acid and valeric acid indicates a reduction in protein fermentation as these short-chain fatty acids are exclusively derived from protein fermentation ${ }^{(46,47)}$. Such fermentation can lead to the formation of toxic metabolites such as $\mathrm{NH}_{3}$ and amines ${ }^{(48)}$ that have been implicated in the clinical expression of diarrhoea ${ }^{(49)}$. Furthermore, the reduction in total VFA concentration in pigs fed the $\mathrm{ZnO}$ diet indicates a decrease in microbial activity in the gastrointestinal tract ${ }^{(49)}$. This may also explain the reduction in the decreased CTTAD of $\mathrm{N}$ in this diet. It is known that $E$. coli breaks down protein as an energy source for its metabolism ${ }^{(49)}$. However, the digestibility measurements were made over the entire gastrointestinal tract, something that may not be accurate because of microbial fermentation in the large intestine. It has been shown that there is significant metabolism of dietary nutrients in the large intestine ${ }^{(50)}$, and subsequently the apparent faecal digestibility method has been labelled as an inaccurate method for the measurement, especially of protein and amino acid digestibility.

The improved performance of pigs fed the laminarin diet observed in the third and fourth weeks of the Expt 2 may be due to a number of reasons. First, the improved performance may be attributable to the improved nutrient digestibility of the diets, and second, the improved performance can be attributable to an increase in Lactobacillus spp. population. The improvement in nutrient digestibility is in agreement with Expt 1 and other studies ${ }^{(11,31)}$, where pigs fed diets containing laminarin had higher CTTAD of gross energy compared with those fed the basal diet.

The increased nutrient digestibility, as a result of laminarin supplementation, may also be due to the increase in the Lactobacillus population. This would suggest that a proportion of the supplemented laminarin is escaping hydrolysis in the foregut and passing into the colon for bacterial fermentation. Furthermore, these bacteria have an ability to produce a wide range of cell-associated polysaccharide depolymerases that may aid in nutrient digestion ${ }^{(31)}$. Laminarin has been shown previously to exhibit prebiotic properties by increasing the populations of Bifidobacterium and Lactobacillus spp. in the large intestine ${ }^{(51,52)}$, thus having a positive effect on gut health. The positive response of growth performance to laminarin may also be attributable to its immunomodulatory effects $^{(13,14)}$. Laminarin supplementation has been shown to suppress the secretion of pro-inflammatory cytokines ${ }^{(14)}$. 
It has been shown that low activation of the immune system during the weaning period could result in an improvement in growth performance ${ }^{(53)}$. However, in the present study, the immunomodulatory effects of laminarin were not measured.

In conclusion, the up-regulation of gene expression of GLUT (GLUT1, GLUT2 and SGLT1), the increase in ADG and $\mathrm{G}: \mathrm{F}$ ratio, the increase in nutrient digestibility and the increase in the population of Lactobacillus spp. suggest that laminarin may provide a dietary means to improve gut health and pig growth performance after weaning.

\section{Acknowledgements}

The present study was financially supported by the Enterprise Ireland Innovation Partnership Programme (Enterprise Ireland) and BioAtlantis Limited (grant no. IP 2009 0030). Enterprise Ireland and BioAtlantis had no role in the design and analysis of the study or in the writing of this manuscript.

The authors' contributions were as follows: G. H. wrote the manuscript, collected samples and carried out the laboratory analyses; J. V. O. D. was the principal investigator responsible for the design of the experiments, supervision of data collection and statistical analysis and correction of the manuscript; T. S. designed the study and corrected the manuscript; A. M. W., D. N. D., C. J. O. S. and M. T. R. contributed to data collection and laboratory analyses; G. H. and M. T. R. contributed equally to the laboratory work. All the authors approved the final version of the manuscript.

None of the authors had a financial or personal conflict of interest in relation to the present study.

\section{References}

1. Maxwell CV \& Carter SD (2001) Feeding the weaned pig. In Swine Nutrition, 2nd ed., pp. 692-715 [AJ Lewis and LL Southern, editors]. Boca Raton, FL: CRC Press.

2. Carroll AJ, Veum TL \& Matteri RL (1998) Endocrine responses to weaning and changes in post-weaning diets in the young pig. Dom Anim Endocrinol 15, 183-194.

3. Pluske JR, Hampson DJ \& Williams IH (1997) Factors influencing the structure and function of the small intestine in the weaned pig: a review. Livest Prod Sci 51, 215-236.

4. Lallès JP, Boudry G, Favier C, et al. (2004) Gut function and dysfunction in young pigs: physiology. Anim Res 53, 301-316.

5. Williams BA, Verstegen MWA \& Tamminga S (2001) Fermentation in the large intestine of single-stomached animals and its relationship to animal health. Nutr Res Rev 14, 207-227.

6. Hu CH, Xiao K, Song J, et al. (2013) Effects of zinc oxide supported on zeolite on growth performance, intestinal microflora and permeability, and cytokines expression of weaned pigs. Anim Feed Sci Technol 181, 65-71.

7. Hu CH, Gu LY, Luan ZS, et al. (2012) Effects of montmorillonite-zinc oxide hybrid on performance, diarrhea, intestinal permeability and morphology or weanling pigs. Anim Feed Sci Technol 177, 108-111.

8. Broom LJ, Miller HM, Kerr KG, et al. (2006) Effects of zinc oxide and Enterococcus faecium SF68 dietary supplementation on the performance, intestinal microbiota and immune status of weaned piglets. Res Vet Sci $\mathbf{8 0}, 45-54$

9. Miller HM, Toplis P \& Slade RD (2009) Can outdoor rearing and increased weaning age compensate for the removal of in-feed antibiotic growth promoters and zinc oxide? Livest Sci 125, 121-131.

10. Gahan DA, Lynch MB, Callan JJ, et al. (2009) Performance of weanling piglets offered low-, medium- or high-lactose diets supplemented with a seaweed extract from Laminaria spp. Animal 3, 24-31.

11. McDonnell P, Figat S \& O'Doherty JV (2010) The effect of dietary laminarin and fucoidan in the diet of the weanling piglet on performance, selected faecal microbial populations and volatile fatty acid concentrations. Animal 4, 579-585.

12. Reilly P, O'Doherty JV, Pierce KM, et al. (2008) The effects of seaweed extract inclusion on gut morphology, selected intestinal microbiota, nutrient digestibility, volatile fatty acid concentrations and the immune status of the weaned pig. Animal 2, 1465-1473.

13. Sweeney T, Collins C, Reilly P, et al. (2012) Effect of purified $\beta$-glucans derived from Laminaria digitata, Laminaria byperborea and Saccharomyces cerevisiae on piglet performance, selected bacterial populations, volatile fatty acids and pro-inflammatory cytokines in the gastrointestinal tract of pigs. Br J Nutr 108, 1226-1234.

14. Walsh AM, Sweeney T, O'Shea CJ, et al. (2013) Effect of dietary laminarin and fucoidan on selected microbiota, intestinal morphology and immune status of the newly weaned pig. Br J Nutr 110, 1630-1638.

15. Wood IS \& Trayhurn P (2003) Glucose transporters (GLUT and SGLT): expanded families of sugar transport proteins. Br J Nutr 89, 3-9.

16. Daniel H (2004) Molecular and integrative physiology of intestinal peptide transport. Annu Rev Physiol 66, 361-384.

17. Hajri T \& Abumrad NA (2002) Fatty acid transport across membranes: relevance to nutrition and metabolic pathology. Annu Rev Nutr 22, 383-415.

18. Glatz JF \& van der Vusse GJ (1996) Cellular fatty acid-binding proteins: their function and physiological significance. Prog Lipid Res 35, 243-282.

19. NRC (1998) Nutrient Requirements of Swine, 10th ed. Washington, DC: National Academy Press.

20. McCarthy J, Aherne F \& Okai D (1974) Use of $4 \mathrm{~N} \mathrm{HCl}$ insoluble ash as an index material for determining apparent digestibility with pigs. Can J Anim Sci 54, 107-109.

21. O'Doherty JV, Nolan CS \& McCarthy PC (2005) Interaction between lactose levels and antimicrobial growth promoters on growth performance of weanling pigs. J Anim Sci of Food Agr 85, 371-380.

22. Pierce KM, Sweeney T, Brophy PO, et al. (2006) The effect of lactose and inulin on intestinal morphology, selected microbial populations and volatile fatty acid concentrations in the gastro-intestinal tract of the weanling pig. Anim Sci 82, 311-318.

23. O'Shea CJ, Sweeney T, Bahar B, et al. (2012) Indices of gastrointestinal fermentation and manure emissions of growing-finishing pigs as influenced through singular or combined consumption of Lactobacillus plantarum and inulin. J Anim Sci 90, 3848-3857.

24. Huijsdens XW, Linskens RK, Mak M, et al. (2002) Quantification of bacteria adherent to gastrointestinal mucosa by real-time PCR. J Clin Microbiol 40, 4423-4427.

25. Penders J, Vink C, Driessen C, et al. (2005) Quantification of Bifidobacterium spp., Escherichia coli and Clostridium difficile in faecal samples of breast-fed and formula-fed infants by real-time PCR. FEMS Microbiol Lett 243, 141-147.

26. Metzler-Zebeli BU, Hooda S, Pieper R, et al. (2010) Nonstarch polysaccharides modulate bacterial microbiota, pathways for butyrate production, and abundance of 
pathogenic Escherichia coli in the pig gastrointestinal tract. Appl Environ Microbiol 76, 3692-3701.

27. Lee C, Kim J, Shin SG, et al. (2006) Absolute and relative qPCR quantification of plasmid copy number in Escherichia coli. J Biotechnol 123, 273-280.

28. Van Soest PJ, Robertson JB \& Lewis BA (1991) Methods for dietary fibre, neutral detergent fibre and non-starch polysaccharides in relation to animal nutrition. J Dairy Sci $\mathbf{7 4}$, 3583-3597.

29. Usov AI, Smirnova GP \& Klochkova NG (2001) Polysaccharides of algae: 55. Polysaccharide composition of several brown algae from Kamchatka. Russ J Bioorg Chem 27, 395-399.

30. O'Connell M, Callan JJ \& O'Doherty JV (2006) The effect of dietary crude protein level, cereal type and exogenous enzyme supplementation on nutrient digestibility, nitrogen excretion, faecal volatile fatty acid concentration and ammonia emissions from pigs. Anim Feed Sci Technol 127, 73-88.

31. O'Doherty JV, McDonnell P \& Figat S (2010) The effect of dietary laminarin and fucoidan in the diet of the weanling piglet on performance and selected faecal microbial populations. Liv Sci 134, 208-210.

32. Boudry G, Peron V, Le Huerou-Luron I, et al. (2004) Weaning induces both transient and long-lasting modifications of absorptive, secretory, and barrier properties of piglet intestine. J Nutr 134, 2256-2262.

33. Pluske JR (2000) Morphological and functional changes in the small intestine of the newly weaned pig. In Gut Environments of Pigs, pp. 1-27 [A Piva, KE Bach Knudsen and JE Lindberg, editors]. Nottingham: Nottingham University Press.

34. Rodriguez SM, Guimaraes KC, Matthews JC, et al. (2004) Influence of abomasal carbohydrates on small intestinal sodium-dependent glucose cotransporter activity and abundance in steers. J Anim Sci 82, 3015-3023.

35. Sangild PT, Tappenden KA, Malo C, et al. (2006) Glucagonlike peptide 2 stimulates intestinal nutrient absorption in parenterally fed newborn pigs. J Pediatr Gastroenterol Nutr 43, 160-167.

36. Shirazi-Beechey SP, Hirayama BA, Wang Y, et al. (1991) Ontogenic development of lamb intestinal sodium-glucose co-transporter is regulated by diet. J Physiol 437, 699-708.

37. Lescale-Matys L, Dyer J, Scott D, et al. (1993) Regulation of the ovine intestinal $\mathrm{Na}+$ /glucose co-transporter (SGLT1) is dissociated from mRNA abundance. Biochem $J \mathbf{2 9 1}$, 435-440.

38. Read SM, Currie G \& Bacic A (1996) Analysis of the structural heterogeneity of laminarin by electrospray-ionisation-mass spectrometry. Carbohydr Res 281, 187-201.

39. Brown GD (2005) Gordon S Immune recognition of fungal $\beta$-glucans. Cell Microbiol 7, 471-479.

40. Ruperez P, Ahrazem O \& Leal JA (2002) Potential antioxidant capacity of sulfated polysaccharides from the edible marine brown seaweed Fucus vesiculosus. J Agri Food Chem 50, $840-845$.
41. Berteau O \& Mulloy B (2003) Sulfated fucans, fresh perspectives: structures, functions, and biological properties of sulphated fucans and an overview of enzymes active toward this class of polysaccharide. Glycobiology 13, 29R-40R.

42. Carlson MS, Hill GM \& Link JE (1999) Early- and traditionally weaned nursery pigs benefit from phase-feeding pharmacological concentrations of zinc oxide: effect on metallothionein and mineral concentrations. J Anim Sci 77, 1199-1207.

43. Molist F, Hermes RG, Segura AG, et al. (2011) Effect and interaction between wheat bran and zinc oxide on productive performance and intestinal health in post-weaning piglets. Br J Nutr 105, 1592-1600.

44. Sargeant HR, Shaw MA, AbuOun M, et al. (2010) The metabolic impact of zinc oxide on porcine intestinal cells and enterotoxigenic Escherichia coli K88. Livest Sci 133, 45-48.

45. Roselli M, Finamore A, Garaguso I, et al. (2003) Zinc oxide protects cultured enterocytes from the damage induced by Escherichia coli. J Nutr 133, 4077-4082.

46. Macfarlane GT, Gibson GR, Beatty E, et al. (1992) Estimation of short-chain fatty acid production from protein by human intestinal bacteria based on branched-chain fatty acids measurements. FEMS Microbiol Ecol 101, 81-88.

47. O'Shea CJ, Lynch MB, Callan JJ, et al. (2010) Dietary supplementation with chitosan at high and low crude protein concentrations promotes Enterobacteriaceae in the caecum and colon and increases manure odour emissions from finisher boars. Livest Sci 134, 198-201.

48. Russell JB, Sniffen CJ \& Van Soest PJ (1983) Effect of carbohydrate limitation on degradation and utilization of casein by mixed rumen bacteria. J Dairy Sci 66, 763-775.

49. Macfarlane S \& Macfarlane GT (2003) Regulation of shortchain fatty acid production. Proc Nutr Soc 62, 67-72.

50. Sauer WC \& Ozimek L (1986) Digestibility of amino acids in swine: results and their practical application: a review. Livest Prod Sci 15, 367-388.

51. Mathers JC \& Annison EF (1993) Stoichiometry of polysaccharide fermentation in the large intestine. In Dietary Fibre and Beyond - Australian Perspectives, pp. 123-135 [S Samman and G Annison, editors]. Perth: Nutrition Society of Australia Occasional Publications.

52. Jaskari J, Kontula P, Siitonen A, et al. (1998) Oat $\beta$-glucan and xylan hydrolysates as selective substrates for Bifidobacterium and Lactobacillus strains. Appl Microbiol Biotechnol 49, 175-181.

53. Li J, Li DF, Xing JJ, et al. (2006) Effects of $\beta$-glucans extracted from Saccharomyces cerevisiae on growth performance, and immunological and somatotropic responses of pigs challenged with Escherichia coli lipopolysaccharide. J Anim Sci 84, 2374-2381.

54. Sauvant D, Perez J-M and Tran G (editors) (2004) Tables of Composition and Nutritional Value of Feed Materials. Pigs, Poultry, Cattle, Sheep, Goats, Rabbits, Horses, Fish. Wageningen, The Netherlands: Wageningen Academic Publishers. 